\title{
DISMANTLING THE STEREOTYPES OF ISLAM, ARAB, AND MUSLIM WOMEN IN THE VISUAL AND PRINT MEDIA OF THE WESTERN WORLD
}

\author{
Tsuroyya Amz \\ Program Studi Ilmu Komunikasi, Fakultas Ilmu Sosial, Universitas Negeri Surabaya
}

\begin{abstract}
Reel Bad Arabs movie indicated that the 9/11 attacks provided a basis for bipolarizing the Western and the Muslims worlds. As a result, a lot of misconceptions of the Muslim world presented in the media embody a rigid concept, comparing and contrasting Western and Islamic/Arabic values in which Western values are favored after the 9/11 attack. Grounded in Reel Bad Arabs and several studies of print media about Islam representations, this paper examined the concepts of Islamophobia focusing on stereotypes of Islam and Arab women as well as the relationship of modernity, capitalism, and Islam as they are perceived by the Muslim world. Employing the agenda-setting theory and basic concepts of Islamophobia, this paper analyzed the selected texts in-depth qualitatively. Correspondingly, previous researches were used to expand the account of the relationship between Islam and the Western media. The analysis claimed that selected print and visual media depict Islam unfavorably leading to a misconception of Islam in the Western world. In fact, stereotypes of Islam proved to be more salient as promoted by the Western media. However, the Muslim media attempted to challenge this by producing several media products such as Kalam Nawaem to show a more "balanced" Islam.
\end{abstract}

Keywords: Stereotypes, media, Muslim, Islamophobia, Islam

\section{MEMBONGKAR STEREOTIP ISLAM, ARAB, DAN WANITA MUSLIM DI MEDIA VISUAL DAN CETAK DUNIA BARAT}

\begin{abstract}
ABSTRAK
Film Reel Bad Arabs mengindikasikan bahwa serangan 11 September 2001 merupakan penyebab pemisah dunia Barat dan Muslim yang berakibat pada miskonsepsi tentang dunia Muslim oleh media dan cenderung menguntungkan nilai-nilai Barat. Melalui film Reel Bad Arabs dan beberapa media cetak lain yang membahas representasi Islam, makalah bertujuan untuk mendiskusikan dan menganalisis secara mendalam konsep fobia Islam khususnya tentang stereotipe Islam dan wanita muslim serta pemahaman dunia muslim terhadap hubungan antara modernitas, kapitalisme, dan Islam dengan menggunakan teori agenda-setting dan konsep dasar Islamophobia oleh Gottschalk dan Greenberg. Makalah ini juga menggunakan penelitian terdahulu tentang media Barat dan Muslim untuk mengeksplorasi hubungan antara kedua media tersebut. Hasil analisis menunjukkan bahwa baik media cetak maupun media visual yang diteliti merepresentasikan Islam sebagai kelompok yang negatif yang berakibat pada miskonsepsi Islam di dunia Barat. Media Barat bahkan terbukti lebih mengutamakan stereotipe Islam. Namun, media Muslim memberikan alternatif lain dengan membuat produk media seperti Kalam Nawaem yang merepresentasikan Islam secara berimbang.
\end{abstract}

Kata-kata Kunci: Stereotipe, media, muslim, fobia-Islam, Islam

Korespondensi: Tsuroyya Amz, S.S., M.A. Program Studi Ilmu Komunikasi, Fakultas Ilmu Sosial, Universitas Negeri Surabaya (Unesa), Jln. Ketintang, Surabaya East Java - Indonesia 60231. Email: amz. tsuroyya@gmail.com 


\section{INTRODUCTION}

Reel Bad Arabs offers a different concept of looking at Western cinema about Arabs and Islam. It meticulously analyzed excerpts of Western cinema that presented stereotypes of Islam and Arabs such as violence, anti-modernity, anti-Western, terrorism, and patriarchal world. The movie discussed how these stereotypes go unchallenged and most Western people take them for granted. The movie indicated that the 9/11 attacks provided a basis for bipolarizing the Western and the Muslims worlds. As a result, a lot of misconceptions of the Muslim world presented in the media embody a rigid concept, comparing and contrasting Western and Islamic/Arabic values in which Western values are favored. Grounded in Reel Bad Arabs and several studies of print media about Islam representations, this paper will discuss the concepts of Islamophobia and orientalism, condensation, and projection, focusing on stereotypes of Islam and Arab women in the text. In addition, this paper will discuss the relationship of modernity, capitalism, and Islam as they are perceived by the Muslim world.

\section{METHODOLOGY}

This paper employed McCombs' and Shaw's agenda-setting theory, particularly framing to show how print and visual media stereotypes of Islam and Arab women as well as the relationship between Islam and the Western concepts outstandingly (Griffin, 2012, p. 381). In doing so, selected visual and print media will be analyzed in-depth qualitatively using the basic concepts proposed by Gottschalk and Greenberg (2008) including orientalism, condensation, and projection particularly presented in the forms of Islam and Arab women stereotypes. The analysis expands the account of the relationship between Islam and the Western media as investigated by previous researchers.

\section{RESULTS AND ANALYSIS}

The term Islamophobia refers to fear of Islam that results from taking any stereotypes of Islam for granted. One is that terrorism involves the so-called holy war to fight against the West. Another definition suggests that

"... increasingly, and particularly among
Muslims, "Islamophobia" provides a term to similarly draw attention to a normalized prejudice and unjustified discrimination. Undoubtedly this term will elicit the same unease among and even backlash from some of those whose notions of normal it challenges, just as its historical predecessors have and still do (Gottschalk and Greenberg, 2008, p. 11).”

In short, Islamophobia conveys a notion of the so-called justified perceptions about Islam and the Arabs, which depict both of them as unfavorable stakeholders. These perceptions define Muslims as "two-faced and untrustworthy, regressive or backward, medieval, and evil (Gottschalk and Greenberg, 2008, p. 76)." In the Reel Bad Arabs, the concept of evil is represented by the repetition of images of male Muslims from the Middle East shouting, firing guns, bombing, and undermining women. There is a consistency in the image repertoire which shapes a stereotype of male Muslims as villains. This "unchallenged stereotype" then justifies the Western assumption that Islam and the Arabs originated from Satan, the evil world.

In addition to the evil stereotype, Reel Bad Arabs also discussed Western cinema that showed the two-faced and untrustworthy stereotype. In several movies selected, Muslims were described as people who were more religious in the way they practiced Islamic rituals. Despite the fact that Muslims were religious, other discourses concentrated more on the evil face of Muslims which was to promote jihad, the holy war, which was, and is, perceived as a war against followers of other faiths. Through this discourse, the West relates jihad with terrorism which embodies a sense of horror and violence. Then, the Western media shape this concept into texts that they produce as news, movies, and advertisements. In fact, the crux of stereotypes of Islam and Arabs which are imposed by the Western perspective is claiming that the Western values are synonymous with modernity, democracy, and flexibility.

Other values, including Islamic and Arabic values, are considered backward and medieval. The text shows most Arab Muslims involved in wars and tending to de-humanize other people through slavery from wars and harims, in which several women entertained Muslim men. As a result of this misconception, these "traditions" is considered old or medieval, practiced only 
by people from past history. On the other hand, depicting Arabs as villains and promoting their cultures as backward and medieval influences media production in a way that they tend to present "half facts" in any case related to Arabs or Islam. In a current example, news about the complexities of the Palestine-Israel conflict is never presented proportionally. In short, those stereotypes indicate the growth of Islamophobia which sees Islam and the Arabs as "other threats."

The concept of "othering" offers another discourse which presupposes a relationship between Islamophobia and orientalism. Concerning Western and Eastern values, McLoughlin (2007) summarizes Said's argument on orientalist stereotype as about the ideological "desires, repressions, investments and projections" of the West itself. In fact, Harb (2008) argues that "orientalism becomes part of a process narrativization that explains the self and orders its experience, making it comprehensible to both individual and society." Prior to this argument, Harb (2008) describes the complexities of an Arab living in the United States. Differences between Western and Eastern values are so rigid that the former is depicted as a favorable stakeholder.

On the other hand, Said (1978: 3) suggests that orientalism is seen as another institution of the Orient and the way to deal with it is "to authorize it, describe it, teach it, settle it, and rule over it". Orientalism thus generates a tremendous influence on Western perspectives of the Middle East and Arabs. These perspectives tend to oversimplify the history of the Middle East and its traditions (The Encyclopedia of Encarta, 2009). In fact, it is common knowledge among the Eastern society that orientalism excludes Indians, Arabs, and West Asian people. Therefore, there is a contradiction in the concept of orientalism itself, yet it continues to divide the world into Eastern and Western points of view which entail complex entities.

Reel Bad Arabs shows how orientalists remained influential in political and economic aspects in the Middle East. It started with the Western control over "oil possession" in the Middle East. As a result, the Organization of the Petroleum Exporting Countries (OPEC) was formed as a legal institution to regulate the circulation of oil around the world. However, other discourse presupposes that OPEC is another form of Western control to maintain its power in the Middle East. Furthermore, OPEC serves as a legal body to minimize chances of an oil embargo taking place against the Western countries.

In regards to the representation of women, orientalism depicts Muslim women as a symbol of oppression, submissiveness, and objects of man's superiority. Wearing a veil remains "abnormal" in the Western perspective as it embodies "force" and "unwillingness" of the women who wear it. In fact, the veil suggests that Muslim men oppress Muslim women to behave based on male Muslims' perspectives. In Reel Bad Arabs, Muslim women were shown as vulnerable stakeholders since they had to obey strict regulations such as wearing a veil, living in isolation, and being submissive toward their husbands. The Westerner perceives a veil, a head covering, as a symbol of being introvert, or, unable to be open-minded. This leads to a concept of isolation which describes barriers to Muslim women being outspoken and outgoing. In most movies, Muslim women are not allowed to go out unaccompanied by a Muslim man, either a husband or a relative. They are supposed to be at home raising their children and doing domestic works.

Obviously, this misconception, derived from most movies, is not prevalent in the real condition of Muslim women. It fails to prove that those stereotypes about Muslim women are actually experienced by Muslim women. Most movies show Muslim women from the Middle East whereas the majority of Muslims live elsewhere -- in East Asia, Central Asia, South Asia, and Southeast Asia. Westerners fail to acknowledge that there are diverse types of Islam and their followers. They persist in believing this "false myth" and perpetuate it in any type of media product.

Although most of the selected movies in Reel Bad Arabs do not favor Arabs or Islam, it is important to note that the movie also showed Dr. Shaheen emphasizing the importance of maintaining a positive outlook that these stereotypes will change. He indicates that dehumanizing Arabs will not continue as media promote a concept of the importance of viewing the other world as diversity, rather than convergence. Media products such as Muhammad: A Legacy of the Prophet and 
Kalam Nawaem represent the Arab world and Islam in a fair way, without distortion. The former is a documentary, which tells the story of the Prophet Muhammad and how his character ceased to perpetuate through Islamic followers. In addition, it also presents stories which affirm that the Islamic world is not medieval, rather has lasted throughout history and remains flexible.

Kalam Nawaem, or Sweet Talk is a talk show designed to build interactive communication mediating Arab women and the Arab community. In addition, this talk show serves as a strategic communication intervention that addresses social issues such as Arab women, education, family, and taboo aspects in the Arab world (PBS, 2007). Through looking at different conflicts that have occurred in the Arab world, Kalam Nawaem presents four Arab women hosts from different Arab countries, ages, and culture ${ }^{1}$. Each represents a specific age and delivers her views on the issue addressed. All of the women are highly educated and they expect that this program to contribute to the development of Arab women (MBC, 2009).

Despite these positive programs, it is important to recognize a growing sentiment toward Islam and the Muslim world, particularly in the form of condensation. In this paper, condensation refers to considering a lot of things, yet favoring other things. After the $9 / 11$ incident people tended to discriminate someone's religious affiliation particularly the Muslims. Eventually, terrorism and crime became identical to Islam whereas neither word shares the same meaning as either Islam or Muslim. The West assumes that both concepts and Islam correlate to each other because the 9/11 attack was done by several Muslims. At this point, the West ignores the human aspect in the incident, that in essence that every human being can commit crimes regardless of his or her religious affiliation. In addition, someone's

\footnotetext{
1 Hosts: Fawziah Salamah, Farah Bseeso, Mona Abo Sulieman, Ranya Bargout. Fawziya Salama, Editor in Chief of Sayidati magazine and a well -respected Egyptian woman living in London; Farah Bseiso, a Palestinian actress and a shining Arab star who lives now in Damascus; and Muna Abousleiman, a young progressive Saudi mother of two and a Ph.D candidate in English Literature.
}

religious affiliation is unlikely to be the basis of delivering punishment in any court.

However, media exposure depicting Muslims as terrorists justifies this analogy that both concepts are identical. In contrast, media balance was questioned when the $\mathrm{Ku}$ Klux Klan (KKK) hunted Jews in the United States. In fact, the media did not highlight the KKK's religious affiliations which allowed people to ignore it. Other examples are the US invasion of Afghanistan and Iraq which suggest that the Western media failed to fulfill their job of maintaining media balance. Obviously, Western media take the United States' side, claiming that democracy was necessary for the sake of Iraq. The Western media did not attempt to view the United States as a non-Muslim people, but rather as liberators. In fact, the Western media reinforce an agenda that religions should be judged based on their followers in spite of their teachings.

As a result of this agenda, the West subconsciously employed two different approaches in favor of the United States in reporting the 9/11 attacks and the US invasion of Iraq. Reel Bad Arabs probes a question of their approach of "othering" Islam and the Muslim world. Yet, the question seems to be rhetorical in that the Western media are unable to offer a reasonable justification for employing such a method. As a matter of fact, Fitna, a Dutch movie which articulates that Western hatred toward Islam and the Muslim media widens the gap between the Muslim and non-Muslim communities. The fact is that Fitna presents a "half concept" of Islam by using several verses from the Holy Koran in an obvious "media war" against the Muslim community. By producing texts such as Fitna, the Western media have categorized Islam into radicals, fanatics, fundamentalists, and liberals. It is the Western perspective that introduces and manifests such concepts into Islam. In contrast, Islam in the era of Prophet Muhammad only acknowledged Islam as a single religion without any classification. Drawing from several examples of how the West frames the Muslim world, it can be concluded that the concept of condensation has been manifested through the Western media, subconsciously or consciously, to maintain Western domination in the global media.

In addition to the concept of condensation, 
Reel Bad Arabs highlights the concept of projection which refers to symbols that are created by the West and projected on the "other". The text discusses the projection of Islamic symbols such as scimitar, mosque, crescent, Muslim men and women, and veil. Each symbol is perceived in two contradictive ways. First, a scimitar is used in war by the US army. However, it characterizes the barbarity of the Muslim community when they use it in a war. Second, a mosque is generally a place where Muslims pray. In contrast, a high exposure in the Western media about terrorism gives the impression that terrorists holding machine guns actually use minarets in mosques as military vantage points. Third, a crescent is basically a type of bread from Vienna and Western people eat it. As the Muslim countries grew, they used it as a symbol on their national flags. This caused the Western audience to associate the symbol with Islam and create a new symbol, a red cross, to counter the popularity of the crescent (Gottschalk and Greenberg, 2008, pp. 46-51).

Another symbol is Muslim men and women who are perceived as villains and introverts. Muslim men are extensively portrayed villains in movies such as Rambo. They are shown bearded and with machine guns. Meanwhile, Muslim women are depicted as both introverted and in "harems." Muslim women with veils are thought to be introverted because they tend to conceal themselves from the world. Western audiences have them is conception that Muslim women are not allowed to leave their houses. On the other hand, several movies in Reel Bad Arabs show that Muslim women are mostly in "harems", present to entertain Muslim men using their bodies. The concept of "harems" and belly dancing depict Muslim men as unfavorable stakeholders as they promote having multiple wives.

In regards to those symbols, it is as if the Western media suggest that anything related to Islam and the Muslim world is considered the "other." As a result, Islam has become the symbol of abnormality so people tend to overlook its stereotypes and created an Islamophobia. Therefore, different treatment for Muslims exists in the field. For instance, in the United States a veiled Muslim woman has to be treated differently when she takes a domestic flight to another city. When she refuses to remove her veil the officer responds that she is responsible for public safety. However, the officer will not execute the same treatment if a veiled nun boards the plane. In this case, it is clear that Islamic symbols greatly influence Western audiences in the way of perceiving those symbols as abnormal.

Extensive exposure in depicting Islam and the Muslim world also takes place in the print media from the Western world. In comparison to what has been shown in Reel Bad Arabs, several scholars have examined how the Western print media frame Islam and the Muslim world. Several studies have suggested that the US mass media inclines to foreground negative aspects of Islam. Ali (2008) documented the coverage of Muslim portrayed by US mass media for the period of 1991-2001. Of the six hypotheses Ali proposed, five were prevalent in the findings that the proportion of negative coverage was greater than the positive. He concluded that the overall portrayal of 12 Muslim countries by Newsweek and Time was dominantly negative (Ali, 2008). However, there was an overlap in Ali's (2008) research. The author categorized 12 Muslim countries into three divisions; US allies, US enemies, and neutral countries. However, the author did not justify the inclusion of Pakistan, a Muslim country which belongs to neither group (Ali, 2008).

A similar study about Islam and the Arab world by Dimitrova and Ahern (2007) examined how online news sites in coalition countries and the Arab world frame news during the Iraq war. They suggested that online news sites from coalition countries such as The New York Times focused on the "greater good" of Iraq's future, whereas the Arab sites "focused more on the personal toll of the war in the present." Their findings assume that the Arab sites foreground the violent aspect of the war. This idea agrees with Ali's conclusion that the Western world focuses more on the negative side of Islam. In other words, the lens of the U.S. mass media and the Western world view Islam, the Arabs, and the Muslim world are identical to violence. To sum up, both cinema and print media from the Western media have extensively manifesting Islam stereotypes and Islamophobia.

It is assumed that promoting the misconceptions of Islam by the Western media is an attempt to endorse modernity to the Muslim world. The West considers its community to be the most modern; therefore they need to help 
other countries modernize as well. The Western world offers a concept of "accepting or rejecting its values." The West, particularly the United States, reinforces this concept through various ways such as IMF structural adjustment, freedom of speech which involves independent media, and Westernization. Countries which reject these programs will be considered anti-West or anti-American. At this point, the concept of modernity contradicts with its original meaning.

In fact, modernity refers to "modernism, innovation, innovativeness, freshness, newness, stylishness, avant-gardism, contemporaneousness, and trendiness (encarta. com)." Looking at the original definition, modernity is supposed to be in the Eastern world where civilization was first acknowledged in Egypt, China, and India. These countries were the ones which invented unique writings as a means of communication. In addition, modernity applied to the Muslim community in the era of Prophet Muhammad. Many Muslim scholars contributed to fields such as medicine, astronomy, and mathematics (algebra). However, these facts seem to be disregarded by the West. Western media mystifies the original meaning of modernity by endorsing a concept of Westernization. They promote democracy as a necessary requirement of a state in which media have to be independent and freedom of speech is an individual right. In this chain of democracy, modernity embeds capitalism as its basis to promote civilization to the developing countries. This idea was prevalent in the presence of IMF structural programs in several Southeast Asian countries such as Indonesia, Vietnam, and Cambodia during the Asian financial crisis in 1997. In fact, IMF encouraged those countries to open their markets as "free market" and by introducing privatization.

By considering that capitalism is pivotal to the West, it is important to note that capitalism is the basis of bipolarizing the West and the East. As suggested in Control Room, an Al Jazeera journalist found out that there was no justifiable rationale for the United States to have invaded Iraq. The Muslim community suspects that the US intervention in Iraq was merely aimed at taking over the oil in the Middle East. Playing the role of the world police department, the United States attempted to free the Iraqi people from the tyrant Saddam Hussain by combating thousands of Iraqi people. At this point, there was a shift in democracy's definition. Originally, democracy was defined as a government by, of, and for the people. Yet, the democracy that was imposed on Iraq is the democratic system of the United States. In other words, the system takes account only from the majority group whereas the minority group is being left behind. In the case of the US invasion of Iraq, the United States was a majority representative, whereas Iraq is the minority.

\section{CONCLUSION}

In conclusion, in an attempt to be the center of the world's mass media, the Western mass media played important roles in creating certain discourses for the world. Such roles seem to be dominated by spectacular issues such as the $9 / 11$ incident. Those roles are manifested in two ways of creating a discourse: "building public opinion and influencing legislatives to resolve foreign policy matters" (Krishna, Nancy and Douglas, 1993). In the case of the $9 / 11$ incident, the US mass media blew up Islam's negative images, for example terrorism, violence, extrovert, fundamentalism, and anti-Westernization. Post $-9 / 11$, most headlines depicted Islam and the Muslim world negatively in order to create a discourse of "global terrorism" and promote US propaganda to combat any terrorism that the world might encounter. It can be assumed that the US mass media generally became the leader of combating terrorism as well as the suspect of degrading Islamic values.

As a result, it is impossible to separate the stereotypes of Islam and the Muslim world from the concepts of Islamophobia and Orientalism. These concepts influence perpetuation of a myth claiming that it is important to differentiate the West and the East. As a matter of fact, it is vital to acknowledge that Western values are the only ones, which fit into the society. Based on this concept, the notion of "othering" emerges, and reinforced through the Western media. Reel Bad Arabs tries to take a different perspective in viewing Western movies. The Reel Bad Arabs shows how unfair the representation of Islam and Arabs in the Western movies is in depicting them as un-favorable stakeholders and promoting their stereotypes. In line with Reel Bad Arabs as well as with other visual texts, scholars have shown that the Western print media also place Islam and the Muslim 
world as the vulnerable group.

In contrast, the Western media extensively promote the propaganda on modernity, Westernization, and capitalism. Based on the previous discussion, it can be assumed that these concepts encourage the process of bipolarizing the East and the West. In addition, they also undermine Islam and the Muslim world. However, there is a belief that the socalled myth will gradually fade as several media present a more "balanced" news on Arab world. It is expected that these products will create a better dialogue between the West and the East leading to a more harmonious life and tolerant society.

\section{REFERENCES}

Ali, S. (2008). US mass media and Muslim world: Portrayal of Muslims by Newsweek and Time[s] (1991-2001). European Journal of Scientific Research, 21 (1450), 544-580.

Dimitrova, D. V. and Ahern, C. C. (2007). A tale of two wars: Framing analysis of online news sites in coalition countries in the Arab world during the Iraq war. The Howard Journal of Communication. 18:153-168, 2007.

Gottschalk, P., and Greenberg, G. (2008). Islamophobia: Making Muslims the enemy. Lanham: Rowman \& Littlefield Publishers,
Inc.

Griffin,E.(2012).AFirstLookat Communication Theory. New York: McGraw Hill.

Harb, S. (2008). Orientalism and the construction of American identity in Abraham Mitrie Rihbany's A Far Journey. Melus, 33(3).

Krishn, J., Signorielli, N., \& McLeod, D. (1993). The evil empire revisited: New York, Times coverage of Soviet intervention in and withdrawal from Afghanistan. Journalism Quarterly, (3), 648.

MBC. (2009). MBC television popular programs. Retrieved March 10, 2009, from http://www.allied-media.com/ARABTV/ MBCprograms.htm.

McLoughlin, S. (2007). Islam(s) in context: Orientalism and the anthropology of Muslim societies and cultures. Beliefs and Values, 28(3), 273-296.

PBS. (2007). Dishing democracy: Introduction. Retrieved March 3, 2009, from http://www. pbs.org/wnet/wideangle/episodes/dishingdemocracy/introduction/973/

Said, E. (1978) Orientalism. London: Penguin. TheEncyclopediaofEncarta.(2009).Edward Said. Retrieved from April 20, 2009, http:// encarta.msn.com/encyclopedia_701701848/ Edward Said.html\#p4. 